(С) Самцов А.В. ${ }^{1}$, Хайрутдинов В.Р. ${ }^{1 \star}$, Соколовский Е.В. ${ }^{2}$, Кохан М.М. ${ }^{3}$, Белоусова И.Э. ${ }^{1}$, Олисова 0.Ю. ${ }^{4}$, Грабовская 0.В. ${ }^{4}$, Бакулев А.Л. ${ }^{5}$, Карамова А.Э. ${ }^{6}$

\author{
${ }^{1}$ Военно-медицинская академия им. С.М. Кирова \\ 194044, Россия, г. Санкт-Петербург, ул. Академика Лебедева, д. 6 \\ 2 Первый Санкт-Петербургский государственный медицинский университет им. акад. И.П. Павлова \\ 197022, Россия, г. Санкт-Петербург, ул. Льва Толстого, д. 6-8 \\ з Уральский научно-исследовательский институт дерматовенерологии и иммунопатологии \\ 620076, Россия, г. Екатеринбург, ул. Щербакова, д. 8 \\ ${ }^{4}$ Первый Московский государственный медицинский университет им. И.М. Сеченова \\ 119991, Россия, г. Москва, Трубецкая ул., д. 8, стр. 2 \\ ${ }^{5}$ Саратовский государственный медицинский университет им. В.И. Разумовского \\ 410000, Россия, г. Саратов, ул. Большая Садовая, д. 137 \\ ${ }_{6}^{6}$ Государственный научный центр дерматовенерологии и косметологии \\ 107076, Россия, г. Москва, ул. Короленко, д. 3, стр. 6
}

В настоящее время единой общепринятой терминологии и классификации васкулитов и сосудистых нарушений кожи нет. В отечественной дерматовенерологии существуют различные подходы к классификации васкулитов кожи - поражения сосудов классифицируют по клиническим признакам, этиологии и патогенезу. Значительные трудности вызывает отсутствие единой терминологии, четких диагностических критериев васкулитов и существование большого количества дублирующих названий, среди которых много эпонимических терминов. Данный вопрос является одним из наиболее сложных, запутанных и дискутабельных не только в дерматовенерологии, но и в других дисциплинах.

Современные принципы диагностики васкулитов кожи базируются на интегральной оценке данных анамнеза заболевания, клинической картины, лабораторных и инструментальных методов обследования. С целью стандартизации определений и диагностических критериев для обсуждения предлагается объединенная рабочая классификация сосудистых поражений, в основу которой положен этиопатогенетический принцип.

Ключевые слова: васкулиты кожи, классификация васкулитов, алгоритм диагностики васкулитов.

Конфликт интересов: авторы данной статьи подтвердили отсутствие конфрликта интересов, о котором необходимо сообщить.

Источник фринансирования: работа выполнена и опубликована за счет фринансирования по месту работы авторов.

Для цитирования: Самцов А.В., Хайрутдинов В.Р., Соколовский Е.В., Кохан М.М., Белоусова И.Э., Олисова О.Ю., Грабовская О.В., Бакулев А.Л., Карамова А.Э. К вопросу о классификации васкулитов кожи. Вестник дерматологии и венерологии. 2021;97(4):48-59. doi: https://doi.org/10.25208/vdv1258 


\title{
Revisiting the question of cutaneous vasculitis classification
}

\author{
(C) Alexey V. Samtsov', Vladislav R. Khairutdinov*, Evgeny V. Sokolovskiy², Muza M. Kokhan³ , Irena E. Belousova1, \\ Olga Yu. Olisova ${ }^{4}$, Olga V. Grabovskaya ${ }^{4}$, Andrey L. Bakulev5 ${ }^{5}$ Arfenya E. Karamova ${ }^{6}$
}

\author{
${ }^{1}$ S.M. Kirov Military Medical Academy \\ Akademika Lebedeva str., 6-8, 194044, Saint Petersburg, Russia \\ ${ }^{2}$ First Pavlov State Medical University of Saint Petersburg \\ Lev Tolstoy str., 6-8, 197022, Saint Petersburg, Russia \\ ${ }^{3}$ Ural Scientific Research Institute of Dermatovenereology and Immunopathology \\ Shcherbakova str., 8, 620076, Ekaterinburg, Russia \\ ${ }^{4}$ Sechenov University \\ Trubetskaya str., 8, bldg 2, 119991, Moscow, Russia \\ ${ }^{5}$ Saratov City Clinical Hospital № 2 named V.I. Razumovsky \\ Bolshaya Sadovaya str., 137, 410000, Saratov, Russia \\ ${ }^{6}$ State Research Center of Dermatovenereology and Cosmetology \\ Korolenko str., 3, bldg 6, 107076, Moscow, Russia
}

Currently, there is no generally accepted terminology and classification of vasculitis and vascular cutaneous disorders. In Russia there are various approaches to the classification of cutaneous vasculitis vascular lesions are classified according to clinical signs, etiology and pathogenesis. Significant difficulties are caused by the lack of a unified terminology, clear diagnostic criteria for vasculitis and the existence of a large number of duplicate names, among which there are many eponymous terms. This issue is one of the most complex, confusing and debatable not only in dermatovenereology, but also in other disciplines. Modern principles of diagnosis of cutaneous vasculitis are based on an integrated assessment of the data of the disease history, clinical picture, laboratory and instrumental methods of examination. For standardization of definitions and diagnostic criteria, it is necessary, first of all, to adopt a unified interdisciplinary classification of vasculitis, which will be based on the etiopathogenetic principle. The applied unified classification of cutaneous vasculitis is proposed for discussion.

Keywords: cutaneous vasculitis, classification of vasculitis, algorithm for diagnosing vasculitis.

Conflict of interest: the authors of this article have confirmed that there is no conflict of interest to declare.

Source of funding: the preparation of the manuscript was carried out by the means of the author's team.

For citation: Samtsov AV, Khairutdinov VR, Sokolovskiy EV, Kokhan MM, Belousova IE, Olisova OYu, Grabovskaya OV, Bakulev AL, Karamova AE. Revisiting the question of cutaneous vasculitis classification. Vestnik Dermatologii i Venerologii. 2021;97(4):48-59. doi: https://doi.org/10.25208/vdv1258 
Васкулиты кожи - гетерогенная группа заболеваний, характеризующихся воспалением стенки кровеносных сосудов кожи. Несмотря на многочисленные исследования по данному вопросу, проблема диагностики и терапии васкулитов кожи остается актуальной в современной дерматовенерологии. Значительные трудности вызывает отсутствие общепринятой классификации, единой терминологии и четких диагностических критериев васкулитов [1].

В отечественной дерматовенерологии в настоящее время существуют различные подходы к классификации васкулитов кожи - поражения сосудов классифицируют по клиническим признакам (морфологическим элементам кожной сыпи), этиологии и патогенезу. Дополнительную путаницу в понимании заболеваний вносит существование большого количества дублирующих названий васкулитов, среди которых много эпонимических терминов, содержащих по несколько фрамилий (например, IgA-васкулит, син.: папулонекротический ангиит, аллергический артериолит, некротический нодулярный дерматит Вертера - Вернера - Дюмлинга, папулонекротический дерматит Вертера - Дюмлинга). В то же время одним термином нередко называют совершенно разные васкулиты, отличающиеся прогнозом и терапевтической тактикой (например, диагноз геморрагический васкулит устанавливается клинически при наличии пальпируемой пурпуры, которая может наблюдаться при IgA-васкулите, всех ANCA-ассоциированных васкулитах, криоглобулинемическом васкулите, IgM/lgG-васкулите, васкулитах при системных заболеваниях, васкулите, ассоциированным со злокачественными заболеваниями и др.) [2, 3].

Создание клинически значимой и простой в использовании классификации васкулитов кожи, включающей клинические признаки, диаметр пораженных сосудов, патоморфологические и лабораторные данные, а также возможные этиологические фракторы, - весьма актуальная на сегодняшний день цель, стоящая перед дерматовенерологами.

Трудности в создании единой классификации васкулитов кожи связаны с их многообразием, клиническим сходством, сложным процессом диагностики данной группы заболеваний. Для решения этой проблемы прежде всего необходимо сформулировать требования к ней. По-видимому, классификация должна быть:

шеждународной - нельзя присваивать существующим заболеваниям собственные названия;

шеждисциплинарной - один васкулит - один диагноз, понятный врачам разных специальностей;

- иметь этиопатогенетический принцип построения диагноз должен быть основой выбора терапевтической тактики;

удобной для использования в практической деятельности.

\section{Ранее предложенные классификации васкулитов кожи}

Попытки создания различных классификаций васкулитов кожи регулярно осуществлялись по мере накопления сведений о данных заболеваниях. В разное время были созданы клинические, этиопатогенетические и патоморфологические классификации, которые учитывали первичные элементы кожной сыпи, размеры и глубину пораженных сосудов, иммунные нарушения, характер течения заболевания.
В 1961 г. болгарский дерматовенеролог Любен Попов создал классификацию, в основу которой был положен этиологический принцип. В этой классификации к васкулитам были отнесены такие заболевания, как узловатая эритема, токсический эпидермальный некролиз, сывороточная болезнь, мигрирующая эритема и др., при которых не происходит повреждения стенки сосудов кожи [4].

\section{Классификация васкулитов (Л. Попов, 1961 г.)}

1. Инфекционные:

пурпура Шенлейна - Геноха;

- ангиодерматит Гужеро - Блюма;

трехсимптомная болезнь Гужеро - Дюперра.

2. Токсико-аллергические, связанные с приемом сульфраниламидов, бутадиена, пирамидона, прокаина, йода и других лекарственных средств:

- узловатая эритема;

- токсические пурпуры;

- токсикоаллергический острый некроэпидермолиз.

3. Анафилактические:

подулярный васкулит Монтгомери, О'Лири и Баркера;

- некоторые мигрирующие фрлебиты;

- аллергический панваскулит Гаркави;

- гранулематозный васкулит Руитера;

- сывороточная болезнь.

4. Аутоиммунные:

узловатый панваскулит;

- флебит Мондора;

мигрирующая эритема.

5. Аллергические васкулиты, развившиеся в результате солнечной радиации, лучистой энергии, метеорологических и температурных влияний.

Среди отечественных дерматовенерологов одними из первых были В.Я. Арутюнов и П.И. Големба (1964), предложившие достаточно подробную классификацию васкулитов, в которой учитывался калибр пораженных сосудов, были выделены поверхностные и глубокие васкулиты кожи, а также системные васкулиты с поражением кожи [5]. В 1975 г. Н.Е. Ярыгин разработал классификацию васкулитов, учитывающую выраженность иммунных нарушений (обратимые - острые и необратимые - хронические) и позволяющую осуществлять определенный выбор тактики лечения [6].

Значительный вклад в изучение сосудистых поражений кожи внесли член-корреспондент АМН СССР профессор С.Т. Павлов и действительный член АМН СССР профрессор О.К. Шапошников, которые попытались систематизировать существующие классификации. Они представили свои результаты на Первой Всесоюзной конференции дерматовенерологов в Ленинграде в 1965 г. В данной классификации учитывалась глубина пораженных сосудов и клинико-морфологические особенности васкулитов [7].

\section{Классификация аллергических васкулитов кожи}

(по С.Т. Павлову и О.К. Шапошникову, 1966 г.)

І. Поверхностные аллергические васкулиты:

1. Геморрагический васкулит (геморрагический капилляротоксикоз).

2. Геморрагический лейкокластический микробид.

3. Узелковый некротический васкулит.

4. Аллергический артериолит.

5. Узелковый периартериит (м. б. глубокие сосудистые поражения). 
II. Глубокие аллергические васкулиты:

1. Острая узловатая эритема.

2. Хроническая узловатая эритема, включающая три клинических варианта:

ш обычная фрорма или подулярный васкулит Монтгомери, О'Лири и Баркера;

мигрирующая узловатая эритема;

подострый мигрирующий гиподермит Вилановы и Пиноля.

С.Т. Павлов и О.К. Шапошников рассматривали аллергические васкулиты как одно из проявлений ангиопатий - обратимых изменений сосудистой стенки, обусловленных ее фризико-химическими нарушениями. В группу ангиопатий также были включены гемосидерозы (пигментно-пурпурозные дерматозы) [7].

\section{Классификация сосудистых заболеваний кожи \\ (по С.Т. Павлову и О.К. Шапошникову, 1974 г.)}

1. Ангионеврозы:

1.1 Болезнь Рейно и синдром Рейно.

1.2 «Мертвый» палец.

1.3 Акроцианоз.

1.4 Livedo reticularis.

1.5 Ознобление.

1.6 Эритроцианоз голеней (асфиктический симметричный отек голеней).

1.7 Розацеа.

2. Ангиопатии:

2.1 Крапивница.

2.2 Аллергические васкулиты.

2.3 Сосудистые дистрофии инфекционно-токсического происхождения.

2.4 Геморрагические диатезы, обусловленные нарушением системы крови.

2.5 Геморрагически-пигментные дерматозы (гемосидерозы).

3. Ангиоорганопатии:

3.1 Облитерирующий эндартериит.

3.2 Диабетическая ангиоорганопатия.

3.3 Гипертонические язвы.

3.4 Livedo racemosa.

3.5 Тромбофлебит.

3.6 Варикозный симптомокомплекс.

3.7 Липоидный некробиоз.

3.8 Хронический дискообразный гранулематоз Miescher-Leder.

4. Сосудистые новообразования.

В классификации С.Т. Павлова и О.К. Шапошникова с учетом современных представлений о васкулитах необходимо выделить следующие недостатки: в настоящее время количество васкулитов кожи стало существенно больше, чем было предложено авторами; лейкоцитокластический васкулит рассматривается как патоморфологический паттерн, а не самостоятельное заболевание и встречается при многих васкулитах; острая и узловатая эритема не относится к васкулитам - это воспаление септ гиподермы без первичного поражения сосудов; узелкового некротического васкулита и аллергического артериолита не существует, вместо этих клинических форм появились различные ANCA-ассоциированные и иммунокомплексные васкулиты [1, 3].

Для практических целей в 1984 г. профессором О.Л. Ивановым была предложена рабочая классифрикация ангиитов (васкулитов) кожи, которая была основана на клинических проявлениях, первичных элементах сыпи и глубине расположения (и соответственно калибре) пораженных сосудов [8].

Классификация ангиитов (васкулитов) кожи

(О.Л. Иванов, 1984 г.)

І. Дермальные ангииты:

1. Полиморфный дермальный ангиит (Синдром Гужеро - Дюперра. Артериолит Рюитера. Болезнь Гужеро - Рюитера. Некротизирующий васкулит. Лейкоцитокластический васкулит):

шртикарный тип (Уртикарный васкулит);

г геморрагический тип (Геморрагический васкулит. Геморрагический лейкоцитокластический микробид Мишера - Шторка. Анафрилактоидная пурпура Шенлейна - Геноха. Геморрагический капилляротоксикоз);

папулонодулярный тип (Нодулярный дермальный аллергид Гужеро);

папулонекротический тип (Некротический нодулярный дерматит Вертера - Дюмлинга);

- пустулезно-язвенный тип (Язвенный дерматит. Гангренозная пиодермия);

шекротически-язвенный тип (Молниеносная пурпура);

- полиморфный тип (Трехсимптомный синдром Гужеро - Дюперра. Полиморфно-нодулярный тип артериолита Рюитера).

2. Хроническая пигментная пурпура (Геморрагически-пигментные дерматозы. Болезнь Шамберга Майокки):

петехиальный тип (Стойкая прогрессирующая пигментная пурпура Шамберга. Болезнь Шамберга);

шелеангиэктатический тип (Телеангиэктатическая пурпура Майокки);

п лихеноидный тип (Пигментный пурпурозный лихеноидный ангиодермит Гужеро - Блюма);

चкзематоидный тип (Экзематоидная пурпура Дукаса - Капенатакиса).

II. Дермо-гиподермальные ангииты:

1. Ливедоангиит (Кожная форма узелкового периартериита. Некротизирующий васкулит. Ливедо с узлами. Ливедо с изъязвлениями).

III. Гиподермальные ангииты:

1. Узловатый ангиит: острая узловатая эритема:

хроническая узловатая эритема (Узловатый васкулит);

пигрирующая узловатая эритема (Вариабельный гиподермит Вилановы - Пиноля. Мигрирующая узловатая эритема Бефверстедта. Болезнь Вилановы).

2. Узловато-язвенный ангиит (Нодулярный васкулит. Нетуберкулезная индуративная эритема).

Рабочая классификация О.Л. Иванова удобна в практической работе дерматовенеролога и интуитивно понятна - по первичному морфологическому элементу сыпи выделяется самостоятельная фрорма васкулита: при папулах с некрозом - папулонекротический тип, при пустулах и язвах - язвенный тип и т. д. Но если рассмотреть данную классификацию с позиций научных знаний сегодняшнего дня, то становится понятным, что она должна быть актуализирована. Например, папулонекротический тип - это клиническое проявление ANCA-ассоциированных васкулитов (микроскопического полиангиита, гранулематоза с полиангиитом или эозинофрильного гранулематоза с полиангиитом), $\operatorname{lgA-васкулита,~васкулита,~ассоциированного~с~вирус-~}$ ным гепатитом $B$, лекарственно-индуцированного иммунокомплексного васкулита, лекарственно-индуцированного ANCA-ассоциированного васкулита, васкулита, 
ассоциированного со злокачественными новообразованиями, или $\mathrm{lgM} / \mathrm{lgG}$ васкулита. Тактика лечения каждого из перечисленных заболеваний имеет существенные отличия: при ANCA-ассоциированных васкулитах необходимы высокие дозы цитостатиков или генно-инженерных биологических препаратов (ГИБП); при $\lg$ A- и lgM/ IgG-васкулитах применяют средние дозы системных кортикостероидов; терапия васкулита, ассоциированного с вирусным гепатитом В, должна включать противовирусные препараты, подавляющие репликацию вируса.

Сведения, которыми мы располагали в XX в., претерпели существенные изменения и дополнения. То, что раньше называли пустулезно-язвенным типом, сейчас это гангренозная пиодермия, которая входит в группу нейтрофрильных дерматозов (при которых поражения сосудов вторичны). Острую узловатую эритему и ее хронические формы в настоящее время относят к септальным панникулитам без васкулита [9]. Вместо ливедо-васкулита (ангиита) описана ливедоидная васкулопатия - самостоятельное заболевание, имеющее клиническое сходство с васкулитами кожи, тогда как в основе васкулопатии лежит гиалинизирующий процесс в сосудах кожи с развитием микротромбоза [10, 11]. Пигментно-пурпурозные дерматозы (устар. хроническая пигментная пурпура) - самостоятельная группа заболеваний кожи, характеризующаяся развитием невоспалительной пурпуры без васкулита. При гемосидерозах нет главного признака васкулита — воспаления стенки кровеносных сосудов кожи [12].

В 1994 г. с целью решения проблемы стандартизированных терминов и определений васкулитов в г. Чапел-Хилл (Северная Каролина, США) был созван специальный комитет, включающий специалистов из шести стран - клиницистов (терапевтов, ревматологов, нефрологов, иммунологов) и патологоанатомов, имеющих наибольший опыт диагностики патологии сосудов. Этот комитет осуществил попытку достижении консенсуса по названиям некоторых наиболее распространенных фрорм васкулитов и ввел международную номенклатуру (Chapel Hill Consensus Conference Nomenclature of Vasculitides, 1994) [13].

\section{Современная классификация васкулитов}

В последующий период произошел существенный прогресс в изучении васкулитов, появилась тенденция к сокращению использования эпонимов в медицинской терминологии. В 2012 г. состоялся второй пересмотр номенклатуры, согласованной на консенсусной конференции Чапел-Хилл (Chapel Hill Consensus Conference-2012 - CHCC-2012). Были введены новые названия, добавлены категории васкулитов. Принятая терминология и определения различных типов васкулитов получили широкое междисциплинарное и международное признание и используются в настоящее время. Номенклатура СНCC-2012 основана на размере пораженных сосудов (с учетом структуры и функции) и механизме развития васкулита [14].

Недостатком номенклатуры CHCC-2012 является отсутствие диагностических критериев васкулитов. Васкулиты кожи вынесены в раздел «Органоспецифические васкулиты - васкулиты одного органа». При этом необходимо отметить, что поражение кожи может наблюдаться практически при всех видах васкулитов, что затрудняет использование данной номенклатуры дерматовенерологами. Рабочая группа Европейской академии дерматологии и венерологии в 2018 г. дополнила существующую номенклатуру СНСС-2012 приложением по дерматовенерологии (D-CHCC), содержащим стандартизированные названия и определения многих васкулитов кожи (табл. 1). Это приложение явилось основой для разработки диагностических критериев васкулитов кожи. Согласно номенклатуре D-CHCC изолированное поражение кожи может наблюдаться как при органоспецифических васкулитах, так и при системных васкулитах с преимущественным поражением кожи. Также сосуды кожи могут вовлекаться в воспалительный процесс при системных васкулитах с полиорганной симптоматикой $[14,15]$.

\section{Объединенная рабочая классификация васкулитов РОДВК}

Рабочая группа Комитета по классификациям РОДВК разработала (в 2020-2021 гг.) объединенную рабочую классификацию васкулитов, дополнив номенклатуру D-CHCC клиническими, патоморфологическими и иммунологическими данными (табл. 2).

Основным принципом диагностики дерматозов, в том числе васкулитов кожи, в настоящее время является комплексная оценка данных анамнеза заболевания, клинической картины, лабораторных и инструментальных методов обследования. При отсутствии результатов иммунологических тестов, гистологического и непрямого иммуногистохимического исследования кожи дерматовенеролог может ограничиться только общим диагнозом «васкулит кожи». Отсутствие полноценного обследования пациентов с патологией сосудов и назначение симптоматической и/или патогенетической (тем более!) терапии на основании исключительно данных клинической картины приводит нередко к диагностическим ошибкам, отсрочке установления верного диагноза и развитию заболевания по неблагоприятному сценарию.

Исходя из предложенной объединенной рабочей классификации васкулитов мы рекомендуем в практической работе использовать разработанный пошаговый алгоритм диагностики васкулитов кожи, изложенный на рис. 1, 2, что облегчает диагностический процесс. Вместе с тем мы хотели бы подчеркнуть, что сама диагностика васкулитов кожи остается сложной и объемной, нередко междисциплинарной работой, правильный результат которой не может быть получен без своевременного гистологического исследования кожи, которое для точной диагностики васкулитов должно проводиться обязательно и на как можно более раннем этапе, до назначения терапии глюкокортикостероидами или цитостатиками.

Несколько десятилетий назад для системной терапии васкулитов можно было использовать только системные ГКС и цитостатики. В настоящее время существует значительный выбор современных системных иммуносупрессивных лекарственных препаратов, список которых постоянно расширяется. Уже накоплен определенный опыт их применения в лечении васкулитов - ингибиторы ФНО- $\alpha$ (инфликсимаб, этанерсепт), ингибиторы IL-1b/IL-1 рецептора (анакинра, канакинумаб), анти-CD20 (ритуксимаб), антагонисты рецептора IL-6 (тоцилизумаб), ингибиторы $\lg \mathrm{E}$ (омализумаб).

В обозримом будущем терапия тяжелых фрорм васкулитов кожи должна становиться более таргетной. 
Таблица 1. Варианты вовлечения сосудов кожи, согласно номенклатуре васкулитов международной консенсусной консреренции (Чапел-Хилл 2012 - СНСС-2012)

Table 1. Variants for the involvement of skin vessels, according to the nomenclature of vasculitis of the international consensus conference (Chapel Hill 2012 - CHCC-2012)

\begin{tabular}{|c|c|c|}
\hline \multirow[b]{2}{*}{ Категория } & \multicolumn{2}{|r|}{ Варианты поражения кожи: } \\
\hline & $\begin{array}{l}\text { проявление } \\
\text { системного } \\
\text { васкулита }\end{array}$ & $\begin{array}{c}\text { системный васкулит с преимущественным } \\
\text { поражением кожи или } \\
\text { органоспецифический васкулит кожи }\end{array}$ \\
\hline \multicolumn{3}{|l|}{ Васкулиты сосудов крупного диаметра: } \\
\hline $\begin{array}{c}\text { Артериит Такаясу } \\
\text { Гигантоклеточный артериит }\end{array}$ & $\begin{array}{l}\text { Нет } \\
\text { Редко }\end{array}$ & $\begin{array}{l}\text { Нет } \\
\text { Нет }\end{array}$ \\
\hline \multicolumn{3}{|l|}{ Васкулиты сосудов среднего диаметра: } \\
\hline $\begin{array}{l}\text { Узелковый периартериит } \\
\text { Болезнь Кавасаки }\end{array}$ & $\begin{array}{l}\text { Да } \\
\text { Нет }\end{array}$ & $\begin{array}{l}\text { Да } \\
\text { Нет }\end{array}$ \\
\hline \multicolumn{3}{|l|}{$\begin{array}{c}\text { Васкулиты сосудов малого диаметра: } \\
\text { ANCA-ассоциированные васкулиты: }\end{array}$} \\
\hline $\begin{array}{c}\text { Микроскопический полиангиит } \\
\text { Грануломатоз с полиангиитом (болезнь Вегенера) } \\
\text { Эозиносрильный грануломатоз с полиангиитом (болезнь Чарга - Стросса) }\end{array}$ & $\begin{array}{l}\text { Да } \\
\text { Да } \\
\text { Да }\end{array}$ & $\begin{array}{l}\text { Да } \\
\text { Да } \\
\text { Да }\end{array}$ \\
\hline
\end{tabular}

Иммунокомплексные васкулиты:

Болезнь с образованием антител к базальной мембране клубочков (анти-GBM болезнь, устар. синдром Гудпасчера)

Криоглобулинемический васкулит

IgA-васкулит (болезнь Шенлейн - Геноха)

Гипокомплементарный уртикарный васкулит (анти-С1q васкулит)

$\begin{array}{lc}\text { Нет } & \text { Нет } \\ \text { Да } & \text { Да } \\ \text { Да } & \text { Да } \\ \text { Да } & \text { Да }\end{array}$

Васкулит с вариабельным поражением сосудов:

$\begin{array}{lcc}\text { Болезнь Бехчета } & \text { Да } & \text { Да } \\ \text { Синдром Когана } & \text { Редко } & \text { Нет }\end{array}$

Васкулиты, ассоциированные с системными заболеваниями:

\begin{tabular}{ccc}
\hline Волчаночный васкулит & Да & Да \\
Ревматоидный артрит & Да & Да \\
Васкулит при саркоидозе & Да & Да \\
Васкулит при других системныхзаболеваниях & Да & Да \\
\hline
\end{tabular}

Васкулиты с установленной (вероятной) этиологией:

Криоглобулинемический васкулит, ассоциированный с вирусным гепатитом C

Васкулит, ассоциированный с вирусным гепатитом В

Лекарственно-индуцированный иммунокомплексный васкулит

Лекарственно-индуцированный ANCA-ассоциированный васкулит Септический васкулит

Васкулит, ассоциированный со злокачественными новообразованиями

$\begin{array}{ll}\text { Да } & \text { Да } \\ \text { Да } & \text { Да } \\ \text { Да } & \text { Да } \\ \text { Да } & \text { Да } \\ \text { Да } & \text { Да }\end{array}$

Органоспецифические васкулиты - васкулиты одного органа (номенклатура СНCC-2012 дополнена):

\begin{tabular}{ccc}
\hline IgM/IgG васкулит & Нет & Да \\
Узловатый васкулит (индуративная эритема Базена) & Дет & Да \\
Эритема возвышающаяся стойкая & Нет & Да \\
Гипергаммаглобулинемический пятнистый васкулит & Нет & Да \\
(гиперглобулинемическая пурпура Вальденстрема) & Нет & Да \\
Нормокомплементарный уртикарный васкулит & Нет & \\
\hline
\end{tabular}

Комментарии: согласно номенклатуре Чапел-Хилл 2012 г. различение сосудов малого и среднего диаметра проводится на основе их структуры и фрункции, а не диаметра. К сосудам малого диаметра относятся интрапаренхимальные малые артерии, артериолы, капилляры, венулы и малые вены, в то время как сосуды среднего диаметра включают магистральные артерии и вены, а также их начальные ветви.

Comments: according to the 2012 Chapel Hill Consensus Conference, small and medium vessels are distinguished on the basis of their structure and function, not diameter. Intraparenchymal small arteries, arterioles, capillaries, venules and small veins are directed to smalldiameter vessels, while medium-diameter vessels include the main arteries and veins, as well as their initial branches. 
Таблица 2. Объединенная рабочая классификация васкулитов РОДВК

Table 2. Applied unified classification of cutaneous vasculitis RSDVC

\begin{tabular}{|c|c|c|c|c|}
\hline Категория & $\begin{array}{c}\text { Название } \\
\text { (шифр МКБ X) } \\
\text { [шифр МКБ XI] }\end{array}$ & Проявления на коже & $\begin{array}{c}\text { Основные патоморфологические } \\
\text { проявления }\end{array}$ & $\begin{array}{c}\text { Дополнительные } \\
\text { диагностические методы }\end{array}$ \\
\hline \multirow{2}{*}{$\begin{array}{c}\text { І. } \\
\text { Васкулиты } \\
\text { сосудов крупного } \\
\text { диаметра }\end{array}$} & $\begin{array}{c}\text { Неспецифический } \\
\text { аортоартериит } \\
\text { (M31.4) [4A44.1] }\end{array}$ & Нет & - & \\
\hline & $\begin{array}{c}\text { Гигантоклеточный } \\
\text { артериит } \\
\text { (M31.6) [4A44.2] }\end{array}$ & Нет & - & $\begin{array}{c}\text { Определение в крови аутоан- } \\
\text { тител к клеткам сосудистого } \\
\text { эндотелия, ферритину }\end{array}$ \\
\hline $\begin{array}{c}\text { ІІ. } \\
\text { Васкулиты } \\
\text { сосудов среднего } \\
\text { диаметра }\end{array}$ & $\begin{array}{c}\text { Узелковый } \\
\text { периартериит } \\
(\mathrm{M} 30.0) \text { [4A44.4] }\end{array}$ & $\begin{array}{c}\text { Ретикулярное ливедо, па- } \\
\text { пулы, узлы, кровоточащие } \\
\text { язвы, петехии, эритема, } \\
\text { пузыри с геморрагическим } \\
\text { содержимым (верхние } \\
\text { и нижние конечности, } \\
\text { лицо, шея) }\end{array}$ & $\begin{array}{c}\text { Поражение артерий и артериол } \\
\text { в подкожной клетчатке, вены не } \\
\text { затрагиваются; воспаление не } \\
\text { распространяется на адвентицию } \\
\text { артерий }\end{array}$ & $\begin{array}{c}\text { Биопсия кожи. } \\
\text { Выявление инфекционных } \\
\text { заболеваний, очагов } \\
\text { хронической инфекции }\end{array}$ \\
\hline
\end{tabular}

А. Микроскопический полиангиит (M31.7) [4A44.A0]

А. Гранулематоз с полиангиитом (M31.3) [4A44.A1]$$
\text { [ }
$$

Эозинофильный гранулематоз с полиангиитом (M30.1)

\section{III.} [4A44.A2]

Васкулить

сосудов малого диаметра:

A - ANCA-acсоциированные васкулиты;

В - иммунокомплексные васкулиты

\section{В. Болезнь с обра- зованием антител к базальной мем- бране клубочков (M31.0) [MK55 - исключено из МКБ]}

В. Криоглобулинемический васкулит [4A44.90]

B. $\lg$ А-васкулит (D69.0) [4A44.92]
Петехии, пальпируемая пурпура, ливедо ретикулярное, папулы с некрозом, узлы, очаговые некрозы (инфаркты) кожи язвенно-некротические изменения слизистой оболочки полости рта и носа (преимущественная локализация: верхние и нижние конечности, чаще в области крупных суставов)

Поражение всех кровеносных сосудов кожи малого диаметра (артериолы, капилляры, венулы), часто с лейкоци токлазией, не встречаются отложения иммунных комплексов. Часто в процесс воспаления вовлекаются подкожные сосуды, включая артерии Отсутствует грануломатозное воспаление в коже или других органах

Поражение сосудов кожи малого диаметра (артериолы, капилляры, венулы), но в сопровождении гранулематозного инфильтрата

Периваскулярные эозинофильные инфильтраты в сочетании с проявлениями васкулита — от нейтрофильного лейкоцитокластического варианта (без выраженной лейкоцитоклазии) с обилием эозинофилов до васкулита артериол, малых артерий или вен. Внесосудистые изменения в виде диффузных интерстициальных инфильтратов в дерме, содержащих многочисленные эозинофилы)
Биопсия кожи. Выявление в крови аутоантител: anti-PR3 ANCA, anti-MPO pANCA

Нет

Петехии, пальпируемая пурпура, изъязвления (участки кожи, подвергающиеся воздействию низкой температуры: кисти, стопы, уши, нос, щеки, возможны также проявления на нижних конечностях)
Лейкоцитокластический васкулит посткапиллярных венул (реже малых вен и артериол) с отложением депозитов из криоглобулинов в пораженных сосудах
Биопсия кожи. Выявление в крови криоглобулинов II и III типа
Петехии, пальпируемая пурпура, папулы с некрозом, пузыри с геморрагическим содержимым (нижние конечности - голени стопы, реже - туловище и верхние конечности). Характерны стойкие волдыри с зудом
Лейкоцитокластический васкулит посткапиллярных венул (реже артериол и малых вен кожи).

При прямой иммунофлуоресценции выявляются $\lg A 1$, образующие депозиты в стенке кровеносных сосудов
Биопсия кожи. Коагулограмма. Определение уровней ЦИК, иммуноглобулинов, криоглобулинов и компонентов системы комплемента, уровней фактора Виллебранда тромбомодулина в плазме крови.

Выявление в крови аутоантител к клеткам сосудистого эндотелия 


\begin{tabular}{cccc}
\hline Категория & $\begin{array}{c}\text { Название } \\
\text { (шифр МКБ X) } \\
\text { [шифр МКБ XI] }\end{array}$ & Проявления на коже & Основные патоморфологические \\
проявления & $\begin{array}{c}\text { Дополнительные } \\
\text { диагностические методы }\end{array}$ \\
\hline
\end{tabular}

В. Гипокомплементемический уртикарный васкулит (M31.8) [4A44.91]

Волдыри, петехии, сетчатое ливедо. Волдыри существуют более 24 часов
Фибриноидный некроз стенки посткапиллярных венул с периваскулярной лейкоцитоклазией и ограниченным отеком сосочкового слоя дермы. При прямой иммунофлуоресценции в сосудистой стенке выявляются депозиты компонентов комплемента и иммуноглобулинов

Биопсия кожи. Выявление в крови анти-С1q антител. Определение уровня компонентов комплемента в крови. С целью выявления тромбофилии - анализ полиморфизма в генах F2, F5, F7, F13, FGB, PAI-1, ITGA2, ITGB3 (риск развития тромбофилии) и MTHFR, MTRR, MTR (нарушения метаболизма фолатов)

\begin{tabular}{|c|c|c|}
\hline \multirow[t]{2}{*}{$\begin{array}{c}\text { IV. } \\
\text { Васкулит с вариа- } \\
\text { бельным пораже- } \\
\text { нием сосудов }\end{array}$} & $\begin{array}{c}\text { Болезнь Бехчета, } \\
\text { (M35.2) [4A62] }\end{array}$ & $\begin{array}{c}\text { Акнеформные фолликуляр- } \\
\text { ные пустулы, нефоллику- } \\
\text { лярные папуло-пустулезные } \\
\text { высыпания, узлы, эрозии, } \\
\text { язвы (верхние и нижние } \\
\text { конечности, гениталии), } \\
\text { возможны тромбозы по- } \\
\text { верхностных и глубоких вен } \\
\text { нижних конечностей, эрозии } \\
\text { и язвы различных размеров, } \\
\text { болезненные на слизистой } \\
\text { оболочке полости рта }\end{array}$ \\
\hline & $\begin{array}{c}\text { Синдром Когана } \\
\text { (H16.3) }\end{array}$ & Нет \\
\hline
\end{tabular}

Поражение сосудов малого диаметра с отеком эндотелия и лейкоцитоклазией, иногда васкулит с фибриноидным некрозом. Тромбоз крупных сосудов развивается при васкулите vasa vasorum. Гистологическое иссле дование узлов в гиподерме выявляет лейкоцитокластический септальный васкулит с обилием гистиоцитов
Биопсия кожи. Положительный тест патергии.

Выявление в крови

аутоантител к клеткам сосудистого эндотелия
Волчаночный

васкулит

(L93.2) [4A40.0Y]

V.

Васкулиты, ассоциированные

с системными заболеваниями
Ревматоидный васкулит (M05.2) [4A44.Y]
Петехии, ретикулярное пиведо, папулы с некрозом (верхние и нижние конечности, туловище, лицо)
Поражение сосудов малого диаметра наиболее часто - посткапиллярных процесс вовлекаются более крупные сосуды. Гистологическая картина обычно соответствует лейкоцитокластическому васкулиту

Спектр изменений - варианты от лейкоцитокластического васкулита посткапиллярных венул с депозитами $\lg \mathrm{M} / \lg \mathrm{G}$, реже - $\lg \mathrm{A}$, до васкулита артерий подкожной клетчатки (гистологическая картина панникулита). Иногда наблюдается воспаление мышечных артерий. Характерным признаком является частое формирование в дерме некробиотических палисадообразных гранулем

Изменения представлены патоморфологическим вариантом лейкоцитокластического или (реже) - грануломатозного васкулита венул, но нередко в воспалительный

саркоидозе

(L95) [4A44.Y]

Васкулит при других системных заболеваниях (L95)

Лекарственноиндуцированный иммунокомплекс-

ный васкулит

(L95) [4A85.030]

Лекарственноиндуцированный ANCA-ассоцииро-
VI.

Васкулиты с установленной (вероятной) этиологией ванный васкулит (L95) [4A85.03Y]

\section{Септический}

васкулит

(L95) [4A44.Y]
Петехии, пальпируемая пурпура, волдыри, папуль с некрозом, язвы (верхние и нижние конечности, туловище)
Биопсия кожи.

Выявление в крови антинуклеарных антител
Биопсия кожи.

Положительный ревматоидный фактор, антитела к циклическому цитруллинированному пептиду
Петехии, пальпируемая пурпура, волдыри, папулы с некрозом, язвы (верхние и нижние конечности, туловище, лицо, полость рта)

Петехии, ретикулярное ливедо (верхние и нижние конечности, туловище, лицо)
Лейкоцитокластический васкулит сосудов малого калибра
Связь с приемом лекарственного препарата (статины, ингибиторы ФНО)

Лейкоцитокластический васкулит сосудов малого калибра

Биопсия кожи.

Связь с приемом
Биопсия кожи. лекарственного препарата.

В крови выявляются ANCA, часто антитела к фосфолипидам

Фибриноидный некроз стенок

сосудов, м. б. лейкоцитоклазия, тромбированные сосуды, отек дермы, экстравазаты эритроцитов, пустулизация эпидермиса
Биопсия кожи. Положительный тест на прокальцитонин и др. маркеры сепсиса
Васкулит, ассоциированный со злокачественными новообразованиями (L95) [4A44.Y]
Петехии, пальпируемая

пурпура, волдыри, папулы

с некрозом, язвы (чаще

нижние конечности)
Биопсия кожи. Обследование на злокачественные опухоли (чаще из лимфоидной ткани) 


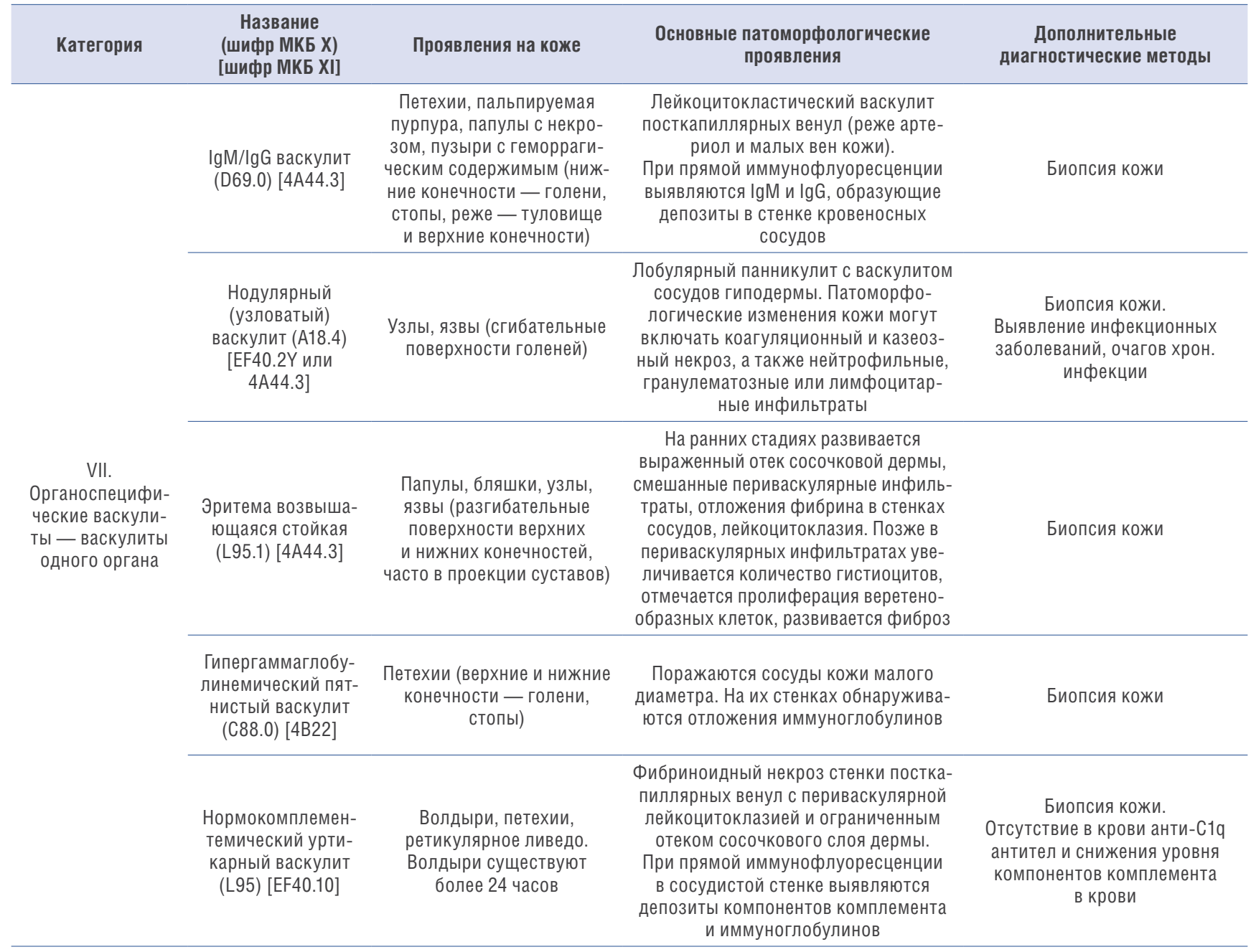

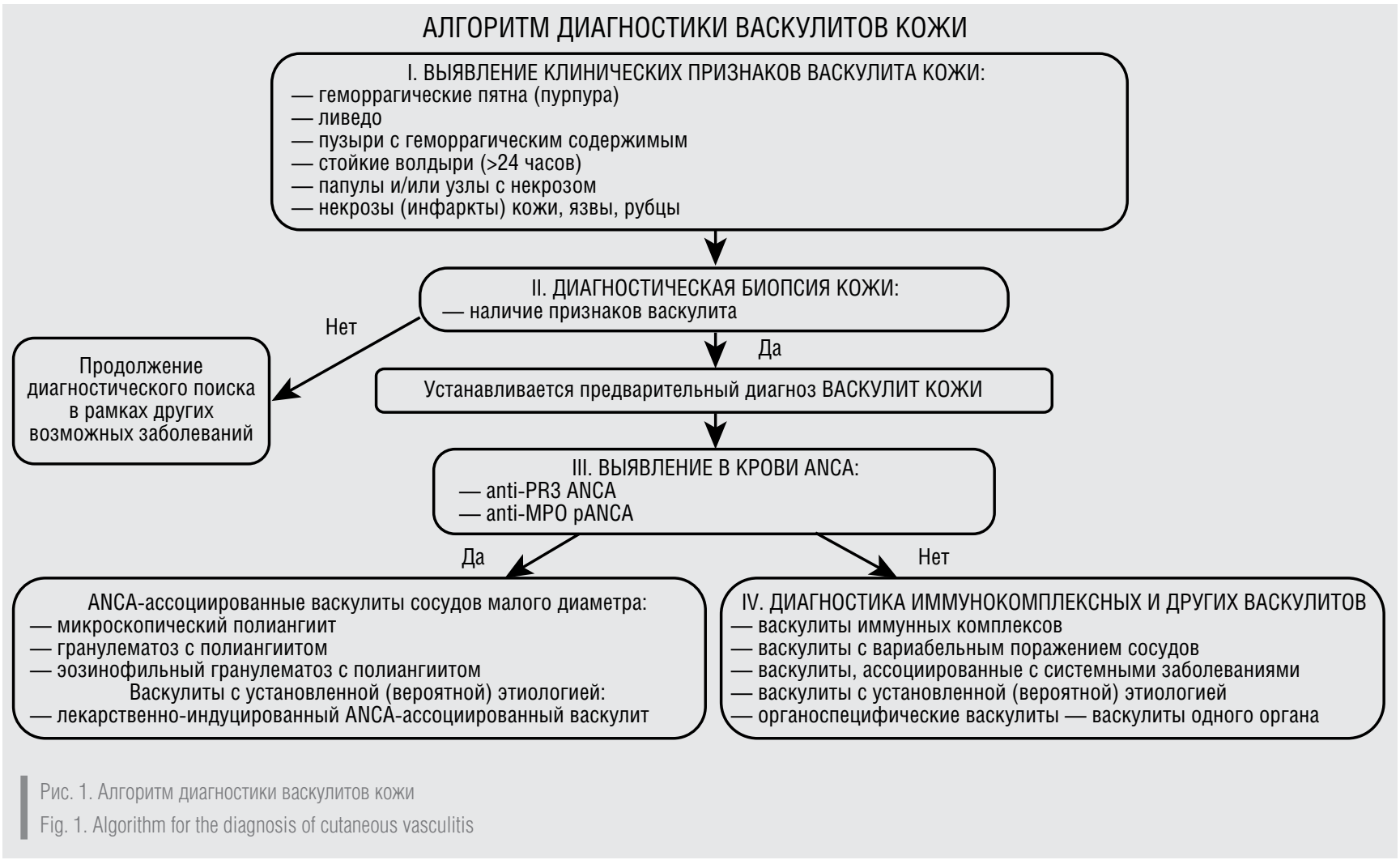




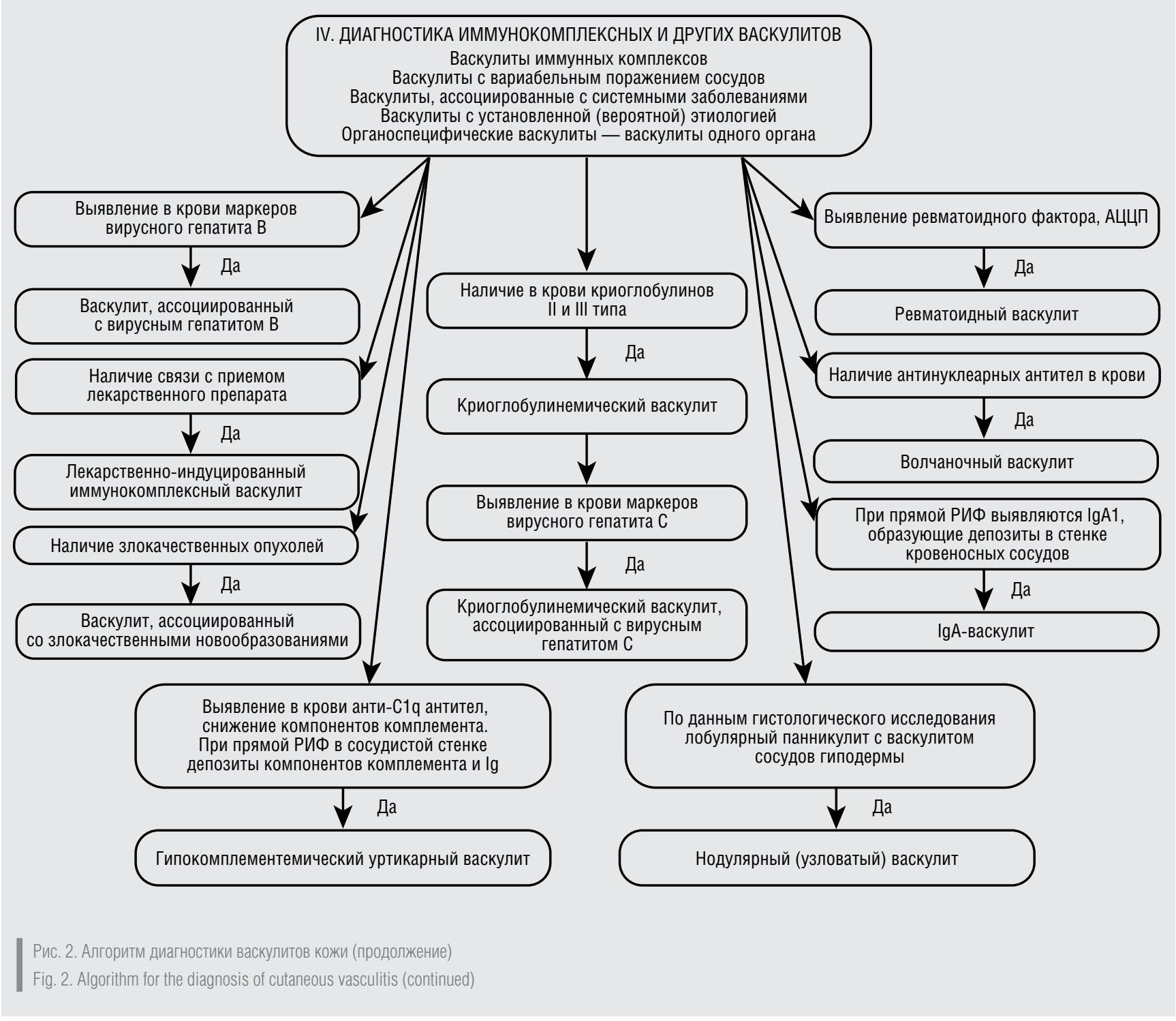

При этом возрастает роль современной комплексной диагностики васкулитов кожи и становится необходимым построение единого междисциплинарного подхода в понимании проблемы сосудистых поражений и использование единой классификации, в основу которой положен этиопатогенетический принцип.

\section{Заключение}

В результате обсуждения различных вариантов классификаций васкулитов рабочая группа Комитета РОДВК по классификациям в дерматовенероло- гии предлагает использовать в клинической работе врачей-дерматовенерологов, в учебных и научных целях - при обучении в медицинских образовательных учреждениях высшего образования, при обучении по специальности «Дерматовенерология» (код ОКСО 3.31.08.32), при планировании и проведении научных исследований, при публикациях в научных медицинских журналах, при разработке Клинических рекомендаций «Объединенную рабочую классификацию васкулитов», изложенную в табл. 2 этой статьи.

\section{Литература/References}

1. Sunderkötter $\mathrm{CH}$, Zelger B, Chen KR, Requena L, Piette W, Carlson JA, et al. Nomenclature of Cutaneous Vasculitis: Dermatologic Addendum to the 2012 Revised International Chapel Hill Consensus Conference Nomenclature of Vasculitides. Arthritis Rheumatol. 2018;70(2):171-184. doi: 10.1002/art.40375
2. Федотов В.П. Васкулиты кожи. Дерматовенерология. Косметология. Сексопатология. 2007;1-4(10):175-193. [Fedotov VP. Cutaneous vasculitis. Dermatovenereology. Cosmetology. Sexopathology. 2007;14(10):175-193 (In Russ.)] 
3. Caproni M, Verdelli A. An update on the nomenclature for cutaneous vasculitis. Curr Opin Rheumatol. 2019;31(1):46-52.

doi: 10.1097/BOR.0000000000000563

4. Попов Л. Синтетическая дерматология. София: Медицина и фризкультура; 1961. С. 309. [Popov L. Synthetic dermatology. Sofia: Medicine and physical culture; 1961. P. 309 (In Russ.)]

5. Арутюнов В.Я., Големба П.И. Аллергические васкулиты кожи. М.: Медицина; 1966. 178 с. [Arutyunov VYa, Golemba PI. Allergic cutaneous vasculitis. Moscow: Medicina, 1966; P. 178 (In Russ.)]

6. Ярыгин Н.Е. Некоторые вопросы морфологии и классификации аллергических васкулитов. Архив патологии. 1975;37(1):45-52. [Yarygin NYe. Some questions of morphology and classification of allergic vasculitis. Archive of pathology. 1975;37(1):45-52 (In Russ.)]

7. Шапошников 0.К., Деменкова Н.В. Сосудистые поражения кожи. Л.: Медицина, 1974; 204 с. [Shaposhnikov OK, Demenkova NV. Vascular cutaneous lesions. L.: Medicine; 1974. P. 204 (In Russ.)]

8. Иванов 0.Л., Бабаян Р.С., Потекаев Н.С. К вопросу о терминологии и клинике васкулитов (ангиитов) кожи. Вестник дерматологии и венерологии. 1984;7:37-42. [Ivanov OL, Babayan RS, Potekaev NS. On the terminology and clinic of cutaneous vasculitis (angiitis). Vestnik dermatologii and venerologii. 1984;7:37-42 (In Russ.)]

9. Wick MR. Panniculitis: A summary. Wick MR. Semin Diagn Pathol. 2017;34(3):261-272. doi: 10.1053/j.semdp.2016.12.004
10. Llamas-Velasco M, Alegría V, Santos-Briz Á, Cerroni L, Kutzner H, Requena L. Occlusive Nonvasculitic Vasculopathy. Am J Dermatopathol. 2017;39(9):637-662. doi: 10.1097/DAD.0000000000000766

11. Georgesen C, Fox LP, Harp J. Retiform purpura: Workup and therapeutic considerations in select conditions. J Am Acad Dermatol. 2020;82(4):799-816. doi: 10.1016/j.jaad.2019.07.113

12. Martínez Pallás I, Conejero Del Mazo R, Lezcano Biosca V. Pigmented Purpuric Dermatosis: A Review of the Literature. Actas Dermosifiliogr (Engl Ed). 2020;111(3):196-204.

doi: 10.1016/j.ad.2019.02.013

13. Jennette JC, Falk RJ, Andrassy K, Bacon PA, Churg J, Gross WL, et al. Nomenclature of Systemic Vasculitides. Arthritis Rheum. 1994;37(2):187-192. doi: 10.1002/art.1780370206

14. Jennette JC, Falk RJ, Bacon PA, Basu N, Cid MC, Ferrario F, et al. 2012 Revised International Chapel Hill Consensus Conference Nomenclature of Vasculitides. Arthritis Rheum. 2013;65:1-11. doi: 10.1002/art.37715

15. Sunderkötter $\mathrm{CH}$, Zelger B, Chen KR, Requena L, Piette W, Carlson JA, et al. Nomenclature of Cutaneous Vasculitis: Dermatologic Addendum to the 2012 Revised International Chapel Hill Consensus Conference Nomenclature of Vasculitides. Arthritis Rheum. 2018;70:171184. doi: $10.1002 /$ art. 40375

Участие авторов: обоснование рукописи, анализ литературных данных и их интерпретация, написание статьи, одобрение рукописи и направление рукописи на публикацию - А.В. Самцов; поисково-аналитическая работа, обоснование рукописи, дизайн статьи, написание статьи, одобрение рукописи и направление рукописи на публикацию - В.Р. Хайрутдинов; анализ литературных данных, разработка концепции и дизайна, написание статьи, одобрение рукописи - Е.В. Соколовский; анализ литературных данных, разработка концепции и дизайна, прочтение, одобрение рукописи - М.М. Кохан; анализ литературных данных, прочтение, одобрение рукописи — И.Э. Белоусова, О.Ю. Олисова, О.В. Грабовская, А.Л. Бакулев, А.Э. Карамова.

Authors' participation: justification of the manuscript, literature analysis and interpretation, writing an article, approval of the submission of the manuscript for publication - Alexey V. Samtsov; search and analytical work, justification of the manuscript, design development, writing an article, approval of the submission of the manuscript for publication - Vladislav R. Khairutdinov; literature analysis, concept and design development, writing and approval of the article - Evgeny V. Sokolovskiy — literature analysis, concept and design development, reading and approving the article - Muza M. Kokhan; literature analysis, reading and approving the article — Irena E. Belousova, Olga Yu. Olisova, Olga V. Grabovskaya, Andrey L. Bakulev, Arfenya E. Karamova.

\section{Информация об авторах}

*Хайрутдинов Владислав Ринатович - д.м.н., доцент, адрес: Россия, 194044, г. Санкт-Петербург, ул. Академика Лебедева, д. 2

Самцов Алексей Викторович - д.м.н., професcop; ORCID iD: https://orcid.org/0000-0002-9458-087; eLibrary SPIN: 2287-5062; e-mail: avsamtsov@mail.ru

Соколовский Евгений Владиславович - д.м.Н., професcop; ORCID iD: https://orcid.org/000-0001-7610-6061, eLibrary SPIN: 6807-7137, e-mail: s40@mail.ru

Кохан Муза Михайловна - д.м.н., профеccop; ORCID iD: https://orcid.org/0000-0001-6353-6644; eLibrary SPIN: 3470-9306; e-mail: mkokhan@yandex.ru

Белоусова Ирена Эдуардовна - д.м.H., профеeccop; ORCID iD: https://orcid.org/0000-0002-4374-4435; eLibrary SPIN: 6386-1117; e-mail: irena.belousova@mail.ru

Олисова Ольга Юрьевна - д.М.H., професcсор; ORCID iD: https://orcid.org/0000-0003-2482-1754; eLibrary SPIN: 2500-7989; e-mail: olisovaolga@mail.ru

Грабовская Ольга Валентиновна - K.M.H.; eLibrary SPIN: 1843-1090; e-mail: olgadoctor2013@yandex.ru

Бакулев Андрей Леонидович - д.м.H., просреccop; ORCID iD: https://orcid.org/0000-0002-1450-4942; eLibrary SPIN: 6708-7386; e-mail: al_ba05@mail.ru

Карамова Арфеня Эдуардовна - K.м.H., доцент; ORCID iD: http://orcid.org/0000-0003-3805-8489; eLibrary SPIN: 3604-6491; e-mail: karamova@cnikvi.ru 


\section{Information about the authors}

*Vladislav R. Khairutdinov - MD, Dr. Sci. (Med.), assistant professor; address: 2 Akademika Lebedeva street, 194044, Saint Petersburg, Russia; ORCID iD: https://orcid.org/0000-0002-0387-5481; eLibrary SPIN: 4417-9117; e-mail: haric03@list.ru

Alexey V. Samtsov - MD, Dr. Sci. (Med.), Professor; ORCID iD: https://orcid.org/0000-0002-9458-087; eLibrary SPIN: 2287-5062; e-mail: avsamtsov@mail.ru

Evgeny V. Sokolovskiy — MD, Dr. Sci. (Med.), Professor; ORCID iD: https://orcid.org/000-0001-7610-6061, eLibrary SPIN: 6807-7137, e-mail: s40@mail.ru

Muza M. Kokhan - MD, Dr. Sci. (Med.), Professor; ORCID iD: https://orcid.org/0000-0001-6353-6644; eLibrary SPIN: 3470-9306; e-mail: mkokhan@yandex.ru

Irena E. Belousova - MD, Dr. Sci. (Med.), Professor; ORCID iD: https://orcid.org/0000-0002-4374-4435; eLibrary SPIN: 6386-1117; e-mail: irena.belousova@mail.ru

Olga Yu. Olisova - MD, Dr. Sci. (Med.), Professor; ORCID iD: https://orcid.org/0000-0003-2482-1754; eLibrary SPIN: 2500-7989; e-mail: olisovaolga@mail.ru

OIga V. Grabovskaya - MD, Cand. Sci. (Med.); eLibrary SPIN: 1843-1090; e-mail: olgadoctor2013@yandex.ru

Andrey L. Bakulev - MD, Dr. Sci. (Med.), Professor; ORCID iD: https://orcid.org/0000-0002-1450-4942; eLibrary SPIN: 6708-7386; e-mail: al_ba05@mail.ru

Arfenya E. Karamova - MD, Cand. Sci. (Med.); ORCID iD: http://orcid.org/0000-0003-3805-8489; eLibrary SPIN: 3604-6491; e-mail: karamova@cnikvi.ru

Статья поступила в редакцию: 30.06 .2021

Принята к публикации: 20.07.2021

Дата публикации: 15.08.2021
Submitted: 30.06 .2021

Accepted: 20.07.2021

Published: 15.08.2021 